\title{
PEMILIHAN TORQUE CONVERTER UNTUK MENINGKATKAN PERFORMA KENDARAAN TRANSMISI OTOMATIS
}

\author{
Deny Nusyirwan \\ Program Studi Teknik Perkapalan, Fakultas Teknik, Universitas Maritim Raja Ali Haji (UMRAH) \\ Jl. Politeknik Senggarang, PO.BOX 155 - Tanjungpinang 29100, Provinsi Kepulauan Riau \\ denynusyirwan@umrah.ac.id
}

\begin{abstract}
Abstrak
Pengalaman berkendara atau di industri otomotif dikenal dengan istilah driving experience adalah merupakan satu aspek yang perlu diperhatikan untuk keberhasilan dalam meningkatkan jumlah penjualan kendaraan. Oleh sebab itu, tidak jarang perusahaan otomotif meluncurkan model dengan pengalaman berkendara yang berbeda untuk pengguna yang berbeda pula, sebagai contoh kendaraaan jenis SUV ( Sport Utility Vehicle), untuk pengendara yang ingin kendaraan yang bersifat responsif, lincah (agile) and presisi. Perusahaan Otomotif sangat menyadari hal ini, oleh sebab itu berusaha untuk meningkat inovasi dalam hal teknologi dengan melakukan uji coba terhadap peningkatan performa kendaraan diantaranya yaitu mesin, roda gigi, berat dan aerodinamis. Didalam penelitian ini akan di fokuskan pada penelitian dengan 3(tiga) jenis torque converter yang diuji coba di lapangan menggunakan kendaraan jenis prototipe akan dibandingkan dengan data yang didapatkan dari simulasi. Pada ahir penelitian akan didapatkan sebuah torque converter yang memiliki Full Load Acceleration yang sesuai untuk kendaraan transmisi otomatis dengan sport driving experience.
\end{abstract}

Kata kunci : pengalaman berkendara, torque converter, prototipe, transmisi otomatis, sport driving

\begin{abstract}
The driving experience as the driving experience is one aspect that needs to be considered for success in increasing the number of vehicle sales. Therefore, it is not uncommon for automotive companies to launch models with different driving experiences for different users, for example SUV (Sport Utility Vehicle) vehicles, for drivers who need vehicles that are responsive, agile and precise. Automotive companies are very aware of this, therefore trying to increase innovation in terms of technology by conducting trials on increasing vehicle performance including engines, gears, weight and aerodynamics. In this study, the focus will be on the research with 3 (three) types of torque converters tested on the test track using prototype vehicles and then compared with simulations. At the end of the study, a torque converter that has a Full Load Acceleration that is suitable for Porsche Cayenne vehicles with sport driving experience will be obtained.
\end{abstract}

Keywords : driving experience, torque converter, prototype, automatic transmission, sport driving

\section{PENDAHULUAN}

Pada saat ini, transmisi pada kendaraan konvensional yang mempergunakan mesin pembakaran internal (Internal Combustion Engine) umumnya diklasifikasikan ke dalam transmisi manual (Manual Transmission), transmisi manual otomatis (Automated Manual Transmission), transmisi otomatis (Automatic Transmission), transmisi kopling ganda (Double Clutch Transmission) dan transmisi variabel kontinu (Continous Variable Transmission) [1] Dengan perbedaaan penggunaan jenis transmisi pada kendaraan akan menimbulkan perbedaaan didalam kehandalan (performance), adapun salah satu hasil inovasi teknologi pada kendaraan dengan transmisi otomatis untuk meningkatkan kehandalan kendaraaan ketika akan berakselerasi maksimal dari posisi diam (Full Load Acceleration) adalah dengan melakukan pemilihan yang tepat terhadap komponen konversi torsi (torque converter). Pada saat kendaraan berakselerasi dari keadaaan diam, mesin harus dengan halus dapat terhubung dengan bagian penggerak sehingga tenaga dapat di pindahkan secara efisien untuk mendapatkan kehandalan yang tinggi ( high performance) ) [2] .

11 Deny Nusyirwan; Pemilihan Torque Converter Untuk Meningkatkan Performa Kendaraan Transmisi Otomatis 


\section{METODE PENELITIAN}

Transmisi otomatis mempergunakan sebuah komponen yang dikenal dengan Torque Converter untuk menggantikan fungsi komponen kopling [3].. Torque converter akan memberikan kenyamanan yang lebih ketika kendaraan berakselerasi dari posisi diam [4] dan akan mengatur mesin dalam keadaaan idle ketika kendaraan tidak bergerak dan posisi perseling dalam keadaan netral [5]. Komponen ini terletak di antara mesin dan transmisi seperti yang dapat dilihat pada Gambar 1.

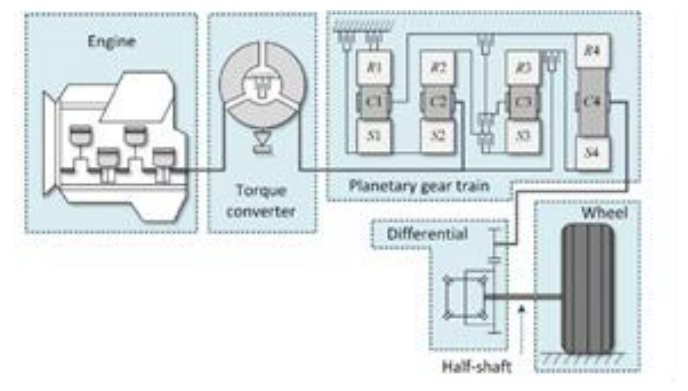

\section{Gambar 1 Lokasi Torque Converter yang terletak di antara mesin dan transmisi [6]}

Didalam proses perancangan sebuah torque converter sebuah kendaraan otomatis, diperlukan tahapan-tahapan perancangan. Dimulai dengan simulasi menggunakan komputer (computer simulation), uji coba purwarupa secara tersendiri di bengkel (stand alone testing) dan uji coba di lintasan pacu (test track). Pada saat tahapan uji coba di lintasan pacu, purwarupa torque converter yang di uji coba sudah di integrasikan dengan kendaraan.

Dalam penelitian ini, menitik beratkan kepada analisa hasil uji coba di lintasan pacu tersebut dengan mengguinakan program simulasi computer untuk mengetahui persamaan dan perbedaaan yang terjadi. Tahapan ini didalam proses perancangan teknik disebut validasi (validation).

Pemanfaatan program simulasi menggunakan komputer sudah menjadi kebutuhan utama di setiap perusahaan otomotif untuk melakukan pengembangan dalam tahapan awal (initial stage) dalam mengurangi biaya penelitian. Hal ini merupakan sebuah kesempatan menarik untuk perusahaan yang bergerak di bidang rekayasa perangkat lunak (software engineering), dapat dilihat dengan semakin banyaknya program-program yang ditawarkan. Sebagai contoh dalam penelitian ini adalah penggunaan program simulasi Cruise dari Perusahaan AVL di Graz, Austria, dimana dapat dipergunakan untuk simulasi kehandalan (performance), kebutuhan bahan bakar (fuel consumsion) dan emisi gas buang kendaraan (emission). Dalam penelitian ini akan di mulai dengan prinsip dasar dan teori-teori yang akan mendukung analisa dan selanjutnya menjelaskan parameterparameter yang akan di pergunakan untuk simulasi. Dalam proses perhitungan nanti akan dilakukan proses iterasi untuk mendapatkan desain dari torque converter yang ketika Full Load Acceleration sesuai dengan karakteristik SUV dengan transmisi otomatis.

Untuk melakukan pengujian terhadap kehandalan dari kendaraan, maka diperlukan pengujian dengan beberapa ketentuan, kondisi pengujian yang pertama adalah pengujian yang berorientasi pada mesin dalam keadaan beban penuh ( full load), kendaraan dalam kondisi mengerem (full brake) dan pedal gas ditekan hingga menyentuh lantai (full gas). Pada kondisi ini putaran pompa pada converter torsi adalah sama dengan putaran motor dan pada turbin adalah 0 (nol) dan kendaraan dalam keadaan tidak bergerak (diam) siap untuk meluncur. Adapun kondisi pengujian yang kedua adalah berorientasi pada pelanggan ketika mengemudi akan berakselerasi dari posisi diam, dimana tanpa perlu menginjak pedal gas penuh sebelumnya. Pedal gas akan di tekan ketika kendaraan akan bergerak. Dari dua kondisi tersebut dapat dilihat akan terjadi perbedaan yang sangat besar adalah pada putaran pompa konverter torsi.

\section{HASIL DAN PEMBAHASAN}

Pada Proses Desain Rekayasa, tahapan validasi adalah tahapan penting untuk seorang rekayasawan sebelum mempergunakan sebuah program simulasi, oleh sebab itu diperlukan validasi terhadap Vehicle Modeller yang terdapat pada AVL Cruise dengan hasil pengukuran yang dilakukan oleh pengemudi tes pada jalur uji.

Pengemudi Tes memiliki tugas melakukan pengujian pada kendaraan generasi berikutnya. Dengan tanggung jawab penuh untuk mengevaluasi kendaraan sesuai dengan proses dan daftar periksa, mendokumentasikan semua cacat fungsi dan kebisingan yang relevan dengan pelanggan yang ditemukan ketika berkendara, berkomunikasi dan menunjukkan permasalahan yang ditemukan spesialis yang bertanggung jawab, dan evaluasi kendaraan dari perspektif pelanggan.

Adapun jenis kendaraan yang dipergunakan adalah kendaraan prototipe, yaitu mobil yang dibuat untuk menampilkan teknologi baru. Mereka sering ditampilkan di pameran motor untuk mengukur reaksi pelanggan terhadap desain baru dan radikal yang mungkin diproduksi secara massal atau tidak.

Pengujian performa dimulai dengan melakukan validasi terhadap akselerasi kendaraan.

Proses pengujian yang dilakukan oleh pengendara uji dilakukan dalam 2(dua) macam, proses pengujian dalam keadaan beban penuh yang 
dikenal dengan istilah testlike, dan pengujian yang mensimulasikan atau orientasikan kepada karakter pelanggan ketika berkendara, dikenal dengan istilah customerlike. Pada Gambar 2 dapat dilihat perbandingan hasil dari simulasi dengan komputer dan hasil pengukuran di lapangan, akselerasi yang dihasilkan tidak mendapatkan perbedaan yang besar.
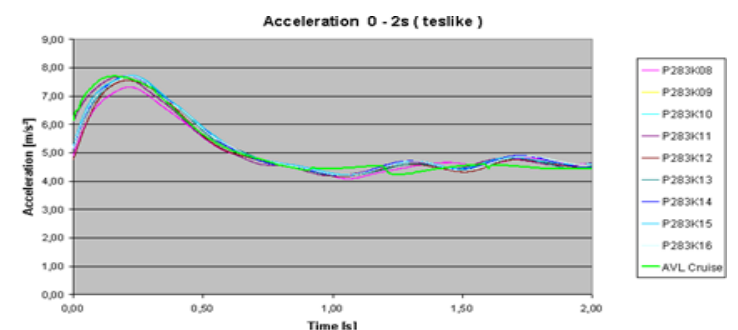

\section{Gambar 2 Akselerasi dengan kondisi testlike}

Begitu juga pada akselerasi kendaraan dengan kondisi customerlike, hasil pengujian dilapangan dan kinhasil simulasi tidak mengalami perbedaan yang besar. Dapat dilihat pada Gambar 3.
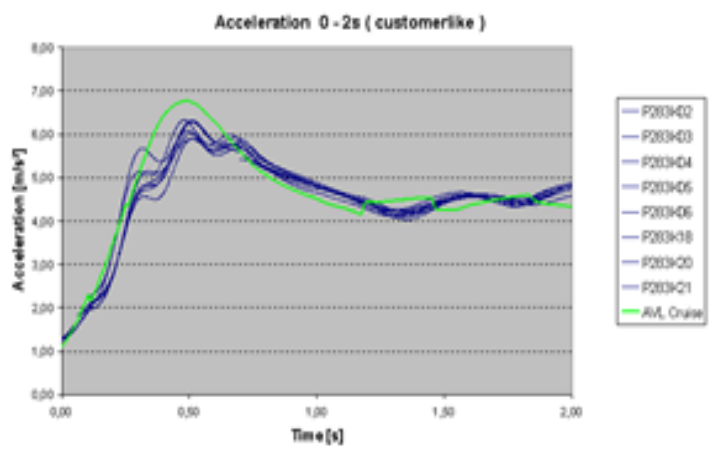

\section{Gambar 3 Akselerasi dengan kondisi customerlike}

Setelah dilakukan validasi pada akselerasi kendaraan, maka langkah selanjutnya adalah validasi pada bagian penggerak kendaraan, yaitu mesin. Pada bagian ini yang perlu diamati adalah putaran mesin pada akselerasi awal kondisi testlike dan customerlike. Dapat dilihat pada Gambar 4, bahwa putaran mesin testlike pada simulasi hampir sama dengan putaran mesin kendaraan purwarupa ketika pengujian.

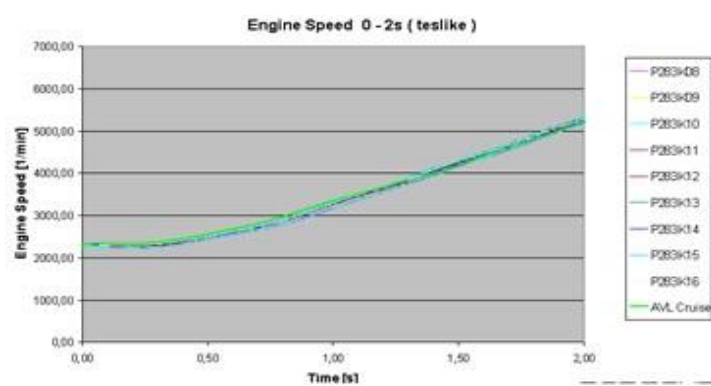

Gambar 4 Putaran mesin dengan kondisi testlike

Begitu juga pada Gambar 5 dimana putaran mesin pada program simulasi sama dengan kondisi pengujian customerlike dengan putaran mesin kendaraaan uji.

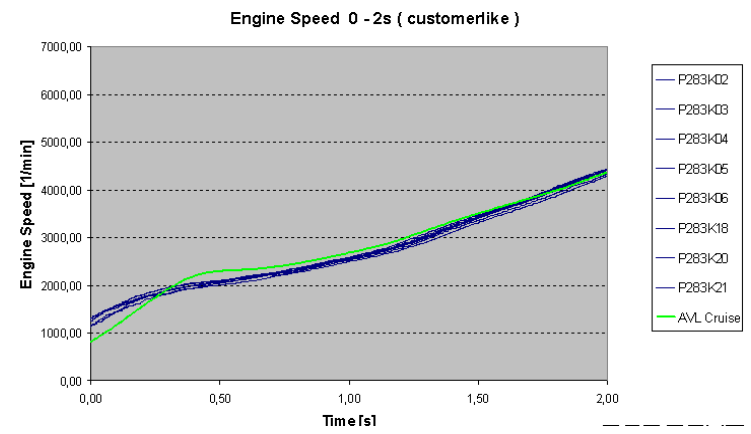

\section{Gambar 5 Putaran mesin dengan kondisi customerlike}

Setelah melalui tahapan validasi akselarasi dan putaran mesin maka tahapan selanjutnya yaitu simulasi untuk mengetahui kinerja kendaraan dengan menggunakan 3(tiga) jenis konverter torsi berbeda.

Didalam prinsip perancangan dikenal 3(tiga) karakter konverter torsi. Tipe Soft (X5), memiliki kemampuan akselerasi yang tinggi, namun konsumsi bahan bakar akan juga tinggi. Tipe Hart (FL), komsumsi bahan bakar yang rendah dan kinerja kendaraan juga rendah. Selanjutnya adalah tipe medium, yang merupakan kompromi dari tipe soft dan hard (REF) [7]. Pada Gambar 6, menunjukkan 3(tiga) data konverter torsi yang masing-masing memiliki karakter yang berbeda. 


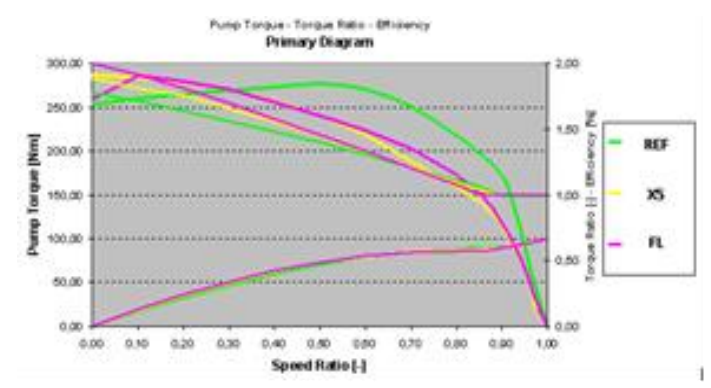

\section{Gambar 6 Karakter Konverter Torsi}

Hasil dari akselerasi yang ditampilkan adalah simulasi dengan kondisi testlike dan customerlike. Pada Gambar 7, menunjukkan akselerasi dari 3 konverter torsi yang ditampilkan menjadi satu tampilan, sedangkan putaran juga mesin ditampilkan untuk dapat langsung melihat karakteristik dari kendaraan pada akselerasi dengan waktu tertentu.

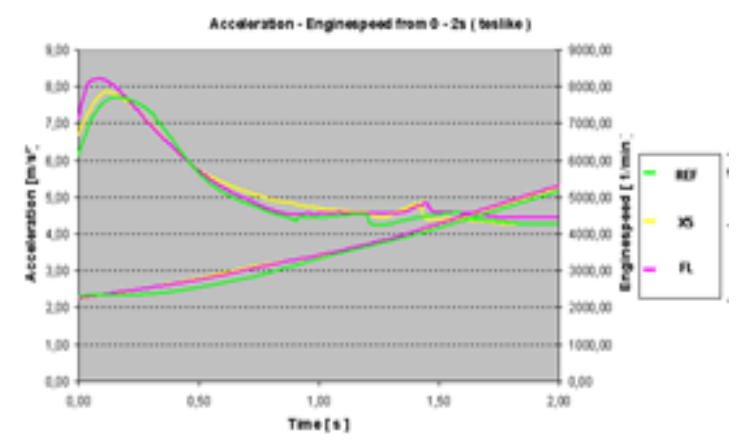

Gambar 7 Akselerasi dan putaran mesin dengan kondisi testlike

Sedangkan pada Gambar 8, menunjukkan hasil simulasi dengan kondisi customerlike.

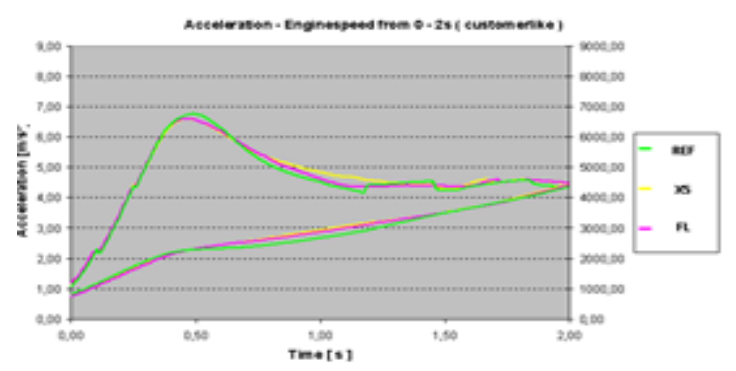

Gambar 8 Akselerasi dan putaran mesin dengan kondisi customerlike

Pada Gambar 9, menampilkan hasil simulasi untuk kecepatan kendaraan dan jarak yang dapat di tempuh dengan kondisi testlike

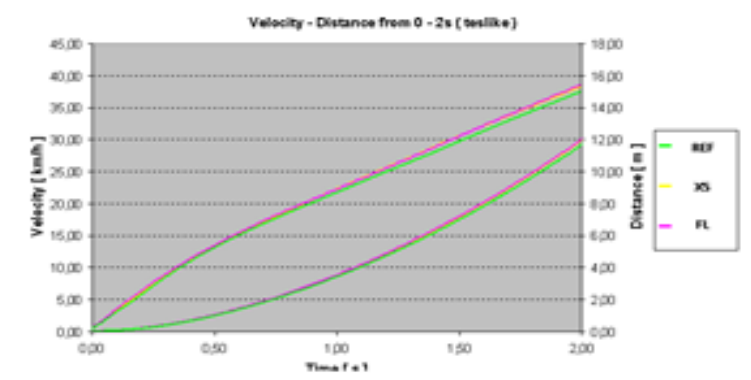

Gambar 9 Kecepatan kendaraan dan jarak yang ditempuh dengan kondisi testlike

Pada Gambar 10., menampilkan hasil simulasi untuk kecepatan kendaraan dan jarak yang dapat di tempuh dengan kondisi customerlike.

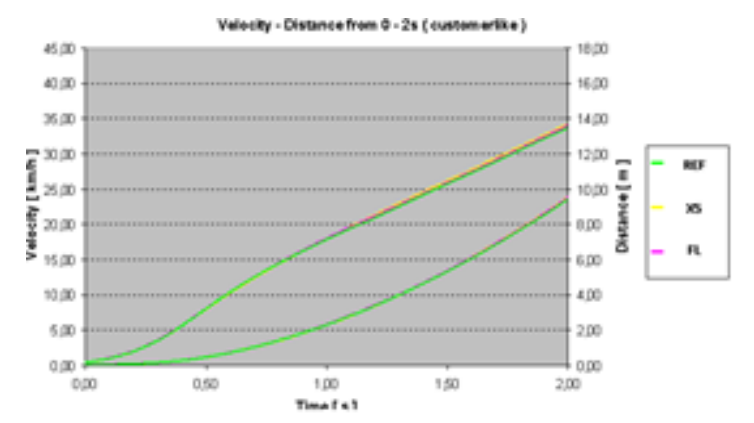

\section{Gambar 10 Kecepatan kendaraan dan jarak} yang ditempuh dengan kondisi customerlien

Pada perbandingan hasil simulasi akan dipergunakan jenis konverter FL sebagai referensi untuk mendapatkan kelebihan dan kekurangan dua jenis lainnya. Dari hasil simulasi tersebut, maka akan didapatkan hasil perbandingan kinerja kendaraan dapat dilihat pada Gambar 11 dan 12 berikut,

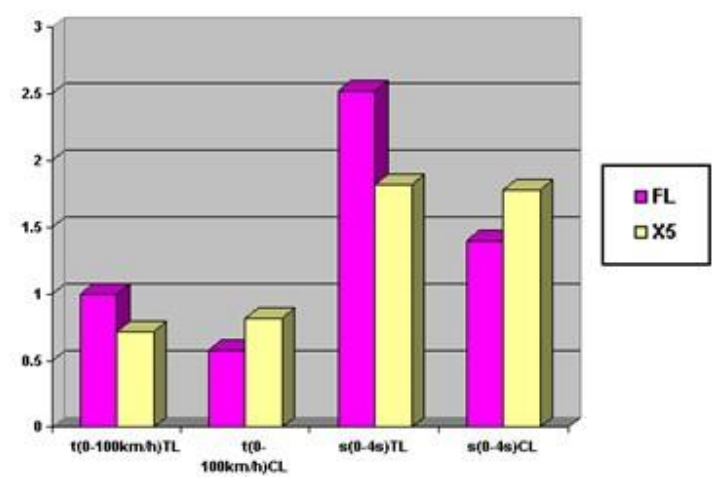

Gambar 11 Potensi perbaikan dibandingkan dengan konverter torsi referensi 


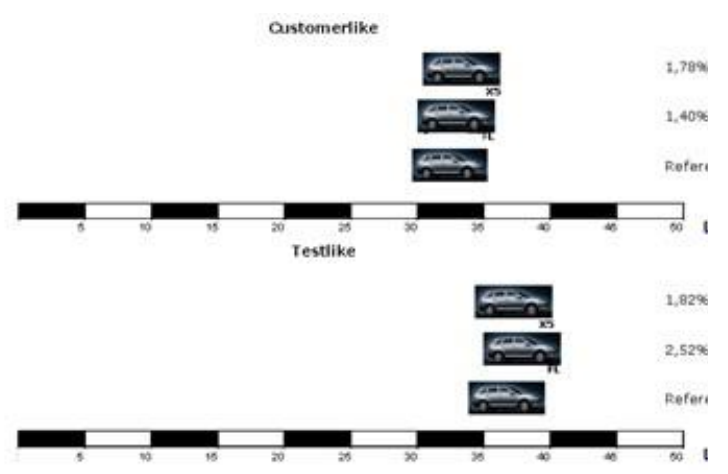

\section{Gambar 12 Jarak yang dapat ditempuh pada waktu 4 detik}

Dari hasil simulasi dengan membandingkan 3 (tiga) jenis konverter torsi yang memiliki karakteristik berbeda. Kendaraan yang mempergunakan konverter torsi jenis FL akan memiliki kinerja yang baik dibanding jenis X5 . Konverter torsi yang memiliki torsi pompa rendah pada bagian awal akan memiliki putaran mesin yang tinggi sehingga akselerasi kendaraan dari posisi diam akan tinggi, juga akan mengakibatkan kendaraan dapat melesat dengan kecepatan labih baik.

\section{KESIMPULAN}

Simulasi adalah proses yang penting didalam proses deain rekayasa, dimana akan dapat menghemat waktu dan biaya. Dalam penelitian ini, menitik beratkan kepada analisa hasil uji coba di lintasan pacu dengan menggunakan program simulasi komputer untuk mengetahui persamaan dan perbedaaan yang terjadi. Tahapan ini didalam proses perancangan teknik disebut validasi (validation). Pemanfaatan program simulasi menggunakan komputer sudah menjadi kebutuhan utama di setiap perusahaan otomotif untuk melakukan pengembangan dalam tahapan awal (initial stage) dalam mengurangi biaya penelitian.

Didalam melakukan proses simulasi diperlukan tahapan validasi, dimana model kendaraan bertransmisi otomatis yang telah dirancang untuk diverifikasi dengan menggunakan hasil uji coba di jalur pacu. Tahapan yang perlu diperhatikan dalam proses ini adalah data-data teknis dan lingkungan ketika uji coba haruslah sesuai dengan yang ada di simulasi. Setelah tahapan validasi ini selesai maka dilanjutkan dengan tahapan pemilihan konverter torsi yang sesuai. Hasil dari simulasi harus mencerminkan dari teori dasar mengenai kolborasi dari karakteristik mesin dan konverter torsi. Dari hasil penelitian ini dapat dengan jelas di lihat tahapan-tahapan pemilihan konverter torsi untuk kendaraan yang memiliki karakteristik SUV.

\section{UCAPAN TERIMA KASIH}

Terima kasih kepada rekan di jurusan teknik elektro Universitas Maritim Raja Ali Haji (UMRAH) yang telah memotivasi untuk melakukan penelitian

\section{DAFTAR PUSTAKA}

[1] I. Wuryandari, Y. S. Gondokaryono, dan I M. Y. Widnyana, " Design and Implementation of Driver Main Computer and Head Up Display on Smart Car", The 4th International Conference On Electrical Engineering and Informatics (ICEEI), 2013

[2] S. N. Doğan, G. Henning, T. Gödecke,M. Sommer, K. Fronius, M. Krohn, J. Kieseland J. Dorfschmid, "Advanced transmission technologies to improve vehicle performance", Daimler AG Germany

[3] S. Sheth, B. R. Gajjar, "A Scope and Study of Automatic TransmissionSystem in Context of Operating Parameter and Professional Requirement", National Conference on Emerging Trends in Engineering, Technology \& Management, 2014

[4] H. Heisler, "Hydrokinetic fluid couplings and torque converters", Advanced Vehicle Technology (Second Edition), 2002

[5] E.G.D Pritchard, R.D. Gould, dan R.R.Johnson, "Torque Converter Interactions in a Parallel Post Transmission Hybrid Driveline", IEEE Vehicle Power and Propulsion Conference, 2011

[6] V. Ranogajec, V. Ivanović, J. Deur, H. E. Tseng,"Optimization-based assessment of automatic transmission double-transition shift controls", Control Engineering Practice, Volume 76, July 2018, hal 155-166

[7] AVL Cruise User's guide version 2.0, AVL LIST GmbH, April 2001 